\title{
SOBRE A POLÍTICA NA IDEOLOGIA ALEMÃ DE MARX E ENGELS
}

\author{
Vilson Aparecido da Mata ${ }^{1}$
}

\section{RESUMO:}

Este artigo resulta de estudos realizados sobre a obra A Ideologia Alemã. O tema central é o duplo caráter da política e a metodologia foi o estudo teórico, tomando o próprio texto como objeto de análise. Esse texto assenta as bases para o Materialismo Histórico e Dialético, bases essas nunca mais abandonadas pelos autores. A estruturação do método materialista dialético, o debate com os contemporâneos mais representativos e a análise de um contexto indicativo de possíveis mudanças radicais na sociedade do século XIX encaminham temas importantes que não podem ser contornados e são, direta ou indiretamente, abordados. A política é um desses temas. Ora falando diretamente sobre ela, ora a colocando com algo subentendido à produção. É assim que o duplo caráter da política se expressa, ao mesmo tempo, como uma positividade, posto ser uma instância confirmadora do humano, construída historicamente a partir da atividade produtiva; e como uma negatividade, uma vez que assume o caráter de irracionalidade ao negar o humano. Como positividade, é ineliminável da vida: ao produzir a própria existência, o ser humano precisa organizar-se socialmente e a instância política é o instrumento para tal. Mas, como negatividade, naquilo que deveria efetivar o humano, a política o desefetiva e esse é o processo tal como ocorre na sociedade capitalista e sob o jugo do liberalismo burguês, objeto também da análise de Marx e Engels nessa obra. Deste modo, entende-se que o duplo caráter da política não pode ser eliminado, ou separado, mas sim que, na atual sociedade capitalista, esse duplo caráter permanece e se constitui em um paradoxo: por um lado, indispensável; por outro, desefetivador do humano.

Palavras-Chave: Política - Ideologia - Materialismo Histórico e Dialético - Democracia

\section{ON POLITICS IN GERMAN IDEOLOGY OF MARX AND ENGELS}

\begin{abstract}
:
This article is the result of studies carried out on the work The German Ideology. The main theme is the double character of the politics and the methodology was the theoretical study, taking the own text as object of analysis. This text settles the foundations for the Dialectical and Historical Materialism, basis never abandoned by the authors. The structuring of the dialectical materialist method, the debate with the most representative contemporaries and the analysis of a context which indicates possible radical changes in the XIXth century society refer to important themes that cannot be avoided and are, directly or indirectly, discussed. Politics is one of these themes. Either talking straight about it, or placing it as something implicit to the production. This is the way the double character of the politics expresses itself, concurrently, positively, once it is a confirming instance of the human being, historically built from the productive activity; and in a negative way, once it assumes the character of irrationality in denying the human. As positivity, it is irremovable from life: by producing its own existence, the human being needs to organize themselves socially and the political instance is the tool for this. However, as negativity, what should implement the human, politics unaccomplishes it and this is the process that occurs in the capitalist society under the judgment of the bourgeois liberalism, also an object of Marx and Engels analysis in this work. This way, it is understood that the double character of politics cannot be eliminated, or separated, but, in the current society, this double character remains and is constituted by a paradox: on the one hand, indispensable; on the other hand , a way to unaccomplish the human.
\end{abstract}

\footnotetext{
${ }^{1}$ É graduado em Educação Física pela Universidade Estadual de Maringá (1991), mestre em Educação pela Universidade Estadual de Maringá - área de concentração em Fundamentos da Educação (2000) e doutor em Educação pela Universidade Federal do Ceará - área de concentração em Filosofia e Sociologia da Educação (2014). Atualmente é professor da Universidade Federal do Paraná (UFPR). Email: vdamata@hotmail.com.
} 
Key-words: Politics - Ideology - Dialectical and Historical Materialism - Democracy

\section{Introdução}

A política é uma categoria recorrente nos textos marxianos. Embora não haja um tratamento sistemático, nem um estudo exaustivo, Marx retorna à questão da política com freqüência em seus escritos, revelando um entendimento claro sobre seu papel na organização da vida social em geral e na sociedade capitalista em particular. Há, na política, um duplo caráter: por um lado, é essencial para a organização social, afirmação do ser humano a partir de sua atividade produtiva e, por outro, é instrumento de repressão, engodo, exploração e corrupção em sua expressão democrático burguesa.

Em alguns casos, a política, o duplo caráter e sua expressão contemporânea são abordados de modo direto por Marx em seus textos, quando o filósofo alemão elabora reflexões a respeito dos acontecimentos de seu tempo, como, por exemplo, em Glosas Críticas Marginais ao Artigo "O Rei da Prússia e a Reforma Social”, de um Prussiano (1844), ou no 18 de Brumário de Luís Bonaparte (1852) e, especialmente, no Manifesto Comunista (1848). Em outras obras, a política aparece como um tema que atravessa a discussão na qual o texto se foca, é o caso, por exemplo, da obra mais conhecida e importante de Marx, O Capital (1865).

Esse duplo caráter da política em Marx pode ser expresso como positividade e negatividade (Chagas, 2014; Mata, 2014). Não se trata de uma oposição monolítica e excludente. Positividade e negatividade são pólos dialéticos presentes na política e inelimináveis da própria essência da sociedade capitalista. Por um lado, a política afirma o humano, uma vez que a organização da sociedade, o modo como os indivíduos se conduzem, aquilo que expressam e a maneira de influenciar as ideias dos outros indivíduos são traços presentes a qualquer formação social. Por outro, os interesses particulares de classe apresentados como interesses universais e institucionalizados como a essência do Estado, a burocracia, o isolamento do indivíduo em relação a sua comunidade são negação do humano, formas de a política expressar e justificar uma concepção ilusória do mundo.

A Ideologia Alemã, de 1845-6, aborda a positividade e a negatividade da política. Elaborada como um acerto de contas de Marx e Engels com o idealismo de Stirner e Bauer e com o materialismo naturalista ainda insuficiente de Feuerbach, essa

\begin{tabular}{|l|l|l|l|l|} 
Govista Qialectus & Ano 4 & n. 11 & Agosto - Dezembro 2017 & p. 244 - 263 \\
\hline
\end{tabular}


obra se constitui como elaboração mais profunda e consistente do Materialismo Histórico e Dialético. É o momento no qual os fundamentos do pensamento de Marx e Engels são firmemente sistematizados e organizados de modo a oferecer os instrumentos teóricos para as análises futuras da sociedade capitalista. Na crítica que os jovens materialistas alemães dirigem a seus contemporâneos, questões a respeito da política ora são tratadas de forma direta, apresentando a posição dos autores em relação à conjuntura por eles vivida; ora aparecem indiretamente, quando são subentendidas em momentos nos quais o foco da discussão não recai sobre a política. $\mathrm{O}$ tema central deste estudo, então, é o duplo caráter da política n'A Ideologia Alemã.

O estudo aqui apresentado está dividido em três partes. Na primeira, apresentase a positividade da política. Em sua atividade produtiva, os indivíduos encaminham também a organização da sociedade. O modo como são engendradas as relações sociais correspondem, necessariamente, a um modo de produzir a existência. Positividade então é a afirmação do humano em sua atividade produtiva. Essa positividade é entendida como essencial à própria organização da vida humana em sociedade, um traço ineliminável, decorrente e determinante da própria práxis.

$\mathrm{Na}$ segunda parte do estudo, apresenta-se a negatividade da política. Como traço ineliminável, necessário, a organização da vida social assume as características do seu tempo histórico, das determinações do próprio modo de produção. É assim que o liberalismo político se impõe como forma de organização da sociedade capitalista, uma vez que eleva à universalidade os interesses particulares de uma classe que apropriou-se dos meios de produção. Em A Ideologia Alemã, essas considerações estão presentes na crítica de Marx e Engels a Stirner e à sua concepção idealista e irreal dos interesses burgueses expressos pelo liberalismo político e suas consequências. A política como engodo e repressão é expressa precisamente no fato de que, sob a égide dos interesses particulares da burguesia, constitui-se como negação do humano.

Ao final, apresentam-se reflexões sobre o duplo caráter da política. Positividade e negatividade são elementos inseparáveis, embora contraditórios, da política na sociedade burguesa. A ideologia surge como falseamento do real quando relacionada com os interesses históricos do capital, contrários aos do trabalho. Nesse sentido, apresentam-se considerações sobre as possibilidades de superação desse falseamento.

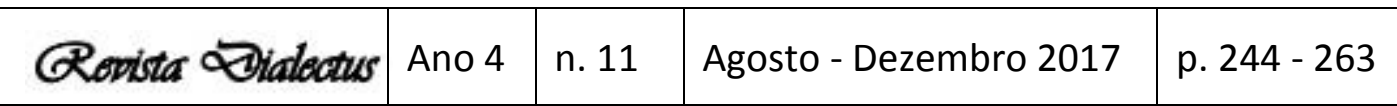




\section{Sobre a Positividade da Política na Ideologia Alemã}

O ser humano é ser de práxis. Afirma-se em sua atividade produtiva e nas relações sociais construídas a partir dela. Há aqui um pressuposto fundamental: os humanos produzem a si mesmos na medida em que produzam o mundo. Esta é uma condição sem a qual a própria existência fica inviabilizada. Não há, portanto, uma essência a priori, mas uma construção constante do mundo como mundo humano. Nas palavras de Marx: "O engendrar prático de um mundo objetivo, a elaboração da natureza inorgânica é a prova do homem enquanto ser genérico consciente, isto é, um ser que se relaciona com o gênero enquanto sua própria essência ou [se relaciona] consigo enquanto ser genérico" (Marx, 2009, p. 85. Grifos do autor).

Esse engendrar prático de um mundo objetivo é fazer coletivo. Em cooperação os indivíduos elaboram a natureza, transformam a matéria natural em coisas que respondem às necessidades de existência, isto é, o ser humano precisa do outro ser humano, é como gênero que os indivíduos transformam a natureza indomada em mundo humano e é nesse processo que o gênero afirma-se em cada indivíduo e cada indivíduo afirma-se como ser pertencente ao gênero humano. Isso implica não somente a produção de instrumentos, alimentos, abrigo, bebida, mas, simultaneamente, a elaboração de relações sociais necessariamente relacionadas com a produção material da vida, ou seja, a partir do trabalho, atividade vital humana, não somente as carências biofisiológicas são satisfeitas, mas as relações sociais que sustentam um modo de vida em um tempo determinado são construídas.

A produção do instrumento para a caça pressupõe a existência de uma presa, mas também relações sociais que organizam a comunidade e demandam a existência de caçadores. As relações sociais que emergem da atividade produtiva são afirmações da engenhosidade humana, da capacidade de fazer um mundo particularmente humano, capacidade esta presente em todo o gênero e em cada indivíduo. É a isso que se denomina, aqui, positividade. Evidentemente, essa positividade limita-se àquilo que afirma. A atividade prática particularmente humana (o trabalho) é uma positividade somente na medida em que afirma o humano. Produzir os meios e as coisas que garantem a existência física dos indivíduos é uma positividade, bem como a organização das relações sociais que sustentam tais produções. A política, a religião, a

\begin{tabular}{|l|l|l|l|l} 
Gevista Dialectus & Ano 4 & n. 11 & Agosto - Dezembro 2017 & p. $244-263$ \\
\hline
\end{tabular}


moral, a linguagem, a estética, etc., são, também, positividade. A cada momento afirmam aquilo que é humano, confirmam as capacidades humanas.

Na obra Ideologia Alemã (Marx e Engels, 2007) é possível apreender a política como elemento que afirma o humano, portanto, há nela uma positividade. Por ser constitutiva da organização das relações sociais, ela é um elemento que se desenvolve conjuntamente com o trabalho, por um lado e, por outro, o organiza e demanda que esta atividade vital seja adaptada a interesses e submetida à forma histórica de uma determinada comunidade. A política encontra-se na base da própria constituição do gênero humano. Esse caráter positivo da política está presente na crítica ao materialismo naturalista ainda eivado de elementos idealistas de Feuerbach. Quando analisam o filósofo "maldito", Marx e Engels demonstram a conexão necessária entre a produção material da vida e sua própria organização. Isso aparece claramente nas considerações sobre a concepção de transformação social, de libertação do ser humano.

Para os filósofos idealistas, a libertação é a emancipação do pensamento. Feuerbach não compartilhava tais ideias, mas também não chegou ao contraponto materialista à revolução da consciência. Em sua contemplação do mundo sensível, Feuerbach o vê como algo sempre igual a si mesmo, dado imediatamente (Marx e Engels, 2007). Para Marx e Engels, a libertação (emancipação) é um ato real (histórico), não um movimento da ideia ou contemplação filosófica do mundo sensível. A libertação real (emancipação humana) é “ocasionada por condições históricas, pelas con[dições] da indústria, do co[mércio], [da agricul]tura, do inter[câmbio]” (Marx e Engels, 2007, p. 29). Em Feuerbach, a revolução como enfrentamento e mudança profunda do estado de coisas existentes é ainda uma contingência.

\footnotetext{
Se, em certos momentos, encontram-se em Feuerbach pontos de vista desse tipo, eles não vão além de intuições isoladas e têm sobre sua intuição geral muito pouca influência para que se possa considerá-los como algo mais que embriões capazes de desenvolvimento. A concepção feuerbachiana do mundo sensível limita-se, por um lado, à mera contemplação deste último e, por outro, à mera sensação (Marx e Engels, 2007, p. 30).
}

Mas, qual o impacto dessas considerações para a positividade da política na Ideologia Alemã ? Em primeiro lugar, é na crítica à concepção feuerbachiana que se desenvolve a importante reflexão sobre o mundo sensível não ser um dado imediato e eterno, mas um produto do trabalho, um produto histórico, resultado da construção

\begin{tabular}{|l|l|l|l|l} 
Gevista Dialectus & Ano 4 & n. 11 & Agosto - Dezembro 2017 & p. $244-263$ \\
\hline
\end{tabular}


coletiva de muitas gerações, "cada uma delas sobre os ombros da precedente, desenvolveram sua indústria e seu comércio e modificaram sua ordem social de acordo com as necessidades alteradas" (Marx e Engels, 2007, p. 30).

Aqui é possível localizar uma relação entre a produção da existência e a organização da sociedade: os indivíduos precisaram desenvolver modos de produção, modos de trocar aquilo que foi produzido e, em consequência, mudar sua própria organização social. A crítica à concepção de Feuerbach oferece os instrumentos para o entendimento de que a política, como instância organizativa da vida social, é um produto também histórico, resultante do trabalho de muitas gerações.

Em segundo lugar, a percepção do mundo não pode ser uma contemplação isolada. O mundo sensível é o mundo humano produzido pelo trabalho. Isso significa que a percepção do mundo só pode ser determinada pelo desenvolvimento histórico das forças produtivas. A natureza que antecedeu o ser humano não existe mais, ela foi transformada pela atividade humana.

E de tal modo é essa atividade, esse contínuo trabalhar e criar sensíveis, essa produção, a base de todo o mundo sensível, tal como ele existe agora que, se ela fosse interrompida mesmo por um ano apenas, Feuerbach não só encontraria uma enorme mudança no mundo natural, como também sentiria falta de todo o mundo dos homens e de seu próprio dom contemplativo, e até mesmo de sua própria existência (Marx e Engels, 2007, p. 31).

As reflexões de Marx e Engels sobre Feuerbach municiam o entendimento de que a produção dos meios de existência encaminha a própria organização da ordem social. O mundo sensível é construído pela atividade produtiva humana, que não é acidental ou ocasional, mas teleológica, organizativa e planejada. Ao exercerem uma atividade consciente, os indivíduos humanos não só garantem os meios materiais para a satisfação de carências imediatas, biofisiológicas, mas organizam as relações sociais porque a produção não pode ocorrer isolada.

Essa concepção necessita pressupostos que demonstrem sua materialidade, ou, que sejam capazes de indicar claramente que o mundo sensível não é somente objeto de contemplação filosófica e tampouco um dado imediato sempre igual a si mesmo, imutável. No esforço empreendido por Marx e Engels para apresentar tais pressupostos

\begin{tabular}{|l|l|l|l|l} 
Gevista Dialectus & Ano 4 & n. 11 & Agosto - Dezembro 2017 & p. $244-263$ \\
\hline
\end{tabular}


encontram-se os pilares do materialismo histórico e dialético, bem como os elementos que nos permitem compreender o caráter positivo da política.

O primeiro pressuposto de que tratam os jovens pensadores alemães diz que, para que haja história, devem existir indivíduos humanos em condições de viver, ou seja, em condições de produzir seu alimento, sua bebida, vestimenta, abrigo (Marx e Engels, 2007, p. 32). A produção dos meios que satisfazem carências humanas não é uma contingência, mas algo que depende de uma organização intencional daquilo que é produzido, do modo como é produzido, como é trocado e como é consumido. Significa também indivíduos vivos organizando a vida social, um ato político, posto que defina quem vai consumir, trocar e produzir, bem como o modo e as condições dessa produção, dessa troca e desse consumo.

O segundo pressuposto explica ser uma decorrência do primeiro o surgimento de novas carências. "É que a satisfação dessa primeira necessidade, a ação de satisfazê-la e o instrumento de satisfação já adquirido conduzem a novas necessidades" (Marx e Engels, 2007, p. 33). A própria organização das relações sociais impacta a produção na medida em que demanda dela novas criações a partir de carências sempre renovadas. A existência de instrumentos de produção pressupõe as condições a partir das quais tal instrumento foi, ele mesmo, produzido, bem como sua finalidade. As condições e a finalidade indicam um contexto e este, por sua vez, indica um determinado modo de produção e, portanto, de organização social.

Tendo já assumido o entendimento de que a produção implica em ato político de organizar a vida social, chega-se aqui a uma importante consequência: ao satisfazer determinadas carências, outras novas aparecem, mas nunca de forma aleatória. As novas carências aparecem a partir e em relação com a forma organizativa da sociedade, da produção, das trocas, etc., e, conforme seja interesse dessa forma organizativa, algumas novas carências serão satisfeitas (criando-se assim novíssimas carências) e outras, aquelas que não forem satisfeitas, permanecem latentes.

O terceiro pressuposto é a reprodução física do ser humano. Uma vez produzindo, satisfazendo e descobrindo novas e novíssimas carências, pressupõe-se uma comunidade que se renova, ou seja, que procria. Produzir novos seres humanos é uma condição que atravessa o fazer histórico, pois não basta renovar diariamente a própria

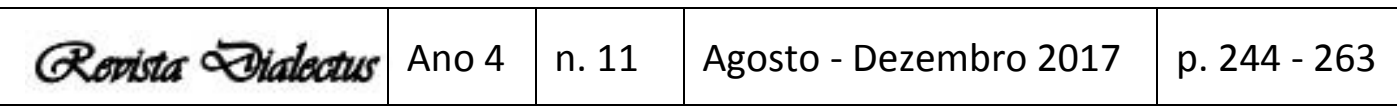


vida, é preciso "criar outros homens, a procriar - a relação entre homem e mulher, entre pais e filhos, a família" (Marx e Engels, 2007, p. 33. Grifo dos autores).

A produção de novos seres humanos indica um modo de organização a que se nomeou família. É uma forma socialmente determinada e historicamente instituída que regula as relações entre os indivíduos, garantindo a reprodução da própria comunidade. A família é uma relação social, uma particularidade que se encontra na base da formação da civilidade, é uma célula política. A primeira relação social do indivíduo se dá na família e só é superada quando as demandas sociais ampliam o seu universo relacional (Cf. Marx e Engels, 2007, p. 33-4).

Os pressupostos apresentados por Marx e Engels indicam que as condições para a existência da sociedade são inseparáveis dos tipos e formas de organização política desenvolvidas a partir da produção real da vida. Essa produção é também reprodução do ser humano e se efetiva em dois aspectos: por um lado, natural, posto o ser humano constituir-se como um dos elementos do mundo sensível, como ser de natureza porque está contido nela e a contém em si. É reprodução natural do humano não somente a procriação, mas a manutenção da existência pela produção do alimento, do abrigo, etc.

Por outro, a produção/reprodução da vida é uma relação social porque pressupõe a cooperação de vários indivíduos, tanto para produzir o alimento, a bebida e o abrigo, quanto para criar novos membros para a sociedade. O caráter social, no entanto, sobrepõe-se ao natural sem abandoná-lo, confirmando a capacidade humana de sobrepujar os limites impostos pela natureza e organizar a produção a fim de aproveitar ao máximo as potencialidades de cada indivíduo para a manutenção da comunidade. É a efetivação da positividade da política. Quando os indivíduos libertam-se de sua dependência absoluta em relação à natureza podem começar a elaborar a vida em sociedade como algo estranho e distante da natureza.

\footnotetext{
Segue-se daí que um determinado modo de produção ou uma determinada fase industrial estão sempre ligados a um determinado modo de cooperação ou a uma determinada fase social - modo de cooperação que é, ele próprio, uma "força produtiva" -, que a soma das forças produtivas acessíveis ao homem condiciona o estado social e que, portanto, a "história da humanidade" deve ser estudada e elaborada sempre em conexão com a história da indústria e das trocas (Marx e Engels, 2007, p. 34).
}

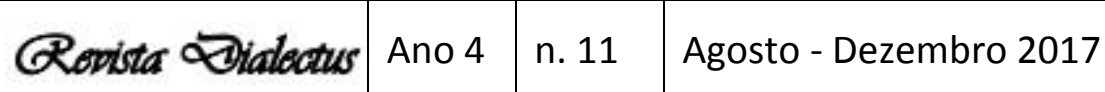

p. $244-263$ 
Parece claro a Marx e Engels que um modo de produção pressupõe cooperação entre os indivíduos e que esse modo de cooperação é uma organização política, portanto, uma "força produtiva" é também uma força organizativa que condiciona a própria forma societária. A história da humanidade é a história dos modos de produção criados e que indicam uma forma de organizar a própria vida dos indivíduos.

O caráter positivo da política evidencia-se na própria atividade produtiva humana. Ao conceber os indivíduos como transformadores do mundo, deve-se compreender também que o mesmo movimento de transformação produz representações sobre o mundo, sobre a relação dos indivíduos entre si e com a natureza: "A produção de ideias, de representações, da consciência, está, em princípio, imediatamente entrelaçada com a atividade material e com o intercâmbio material dos homens, com a linguagem da vida real" (Marx e Engels, 2007, p. 93).

E a linguagem da vida real indica que os indivíduos, produzindo de uma determinada maneira, estabelecem "entre si estas relações sociais e políticas determinadas" (Marx e Engels, 2007, p. 93). Para os jovens pensadores alemães a conexão entre a estrutura social e política e a produção deve ser explicitada sem mistificação. Não se pode pensar a existência de seres humanos produzindo isolados, ou sem que essa produção demande cooperação, uma certa organização social e a estrutura política. É por isso que

\footnotetext{
A estrutura social e o Estado provêm constantemente do processo de vida de indivíduos determinados, mas desses indivíduos não como podem aparecer na imaginação própria ou alheia, mas sim tal como realmente são, quer dizer, tal como atuam, como produzem materialmente e, portanto, tal como desenvolvem suas atividades sob determinados limites, pressupostos e condições materiais, independentes de seu arbítrio (Marx e Engels, 2007, p. 93. Grifo dos autores).
}

A positividade da política é aqui revelada. As relações sociais que emergem da produção/reprodução da vida são a confirmação do humano. Mas não uma confirmação idealizada. Aquilo que os indivíduos pensam sobre si mesmos deve ser confrontado com aquilo que realmente são. É que, em determinado momento, a organização da vida social pode parecer algo distante e diferente da produção material da vida, algo desvinculado dela. Para compreender a positividade da política, é preciso analisar o modo como a atividade produtiva está organizada e como ela impacta a própria forma

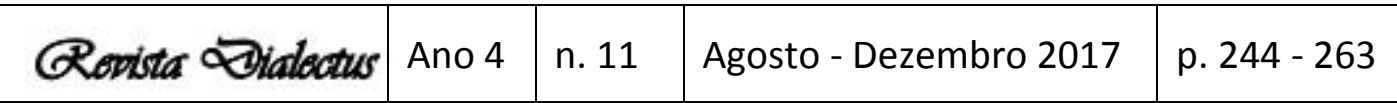


como os indivíduos, em determinado momento da história, produzem, o que produzem, quem tem acesso a essa produção, etc.

\section{Sobre a Negatividade da Política na Ideologia Alemã}

A exposição a respeito da positividade da política esclarece seu caráter de afirmação do humano. Entretanto, havendo uma positividade, necessariamente haverá uma negatividade. Quando se apresenta a positividade da política como uma racionalidade definidora do que é indispensável para a sociedade humana, daquilo que faz da sociedade a afirmação coletiva de cada indivíduo em particular e de cada indivíduo a afirmação da comunidade, então a negatividade deverá ser entendida, neste texto, como a irracionalidade, como a negação do humano em um dos aspectos determinantes de sua afirmação social: a política.

A política, então, assume também o caráter de negação, de irracionalidade, de desefetivação. A produção, como se viu até aqui, implica a própria organização da vida social e essa organização é um ato político. Na moderna sociedade capitalista, essa organização resultou na decomposição das atividades de produção/reprodução mais complexas em tarefas simples. A divisão do trabalho se efetivou como a própria instância definidora da vida social: “o capital se apoderou da divisão do trabalho, reconfigurando-a radicalmente para seus propósitos ao longo de sua história” (Harvey, 2016, p. 111).

No entendimento de Marx e Engels (2007), é a partir da divisão do trabalho em material e espiritual que fica instituída, por exemplo, a oposição entre campo e cidade e, com isso, a necessidade da administração, da polícia, dos impostos, enfim, do aparato burocrático e material do Estado, da política formalmente institucionalizada. A divisão entre campo e cidade é, à época dos jovens autores alemães, a expressão mais representativa da divisão do trabalho na sociedade capitalista, nas suas exatas palavras:

A cidade é, de pronto, o fato da concentração da população, dos instrumentos de produção, do capital, das fruições, das necessidades, enquanto o campo evidencia exatamente o fato contrário, a saber, o isolamento e a solidão. A oposição entre cidade e campo só pode existir no interior da propriedade privada (Marx e Engels, 2007, p. 53).

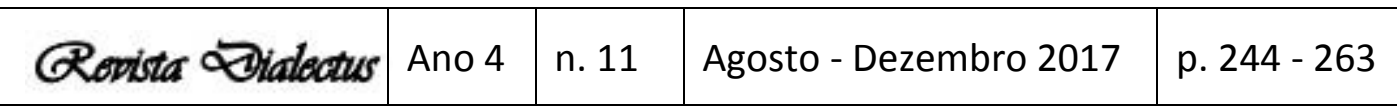


Na formulação de Marx e Engels (2007), os indivíduos estão de tal modo subsumidos à divisão do trabalho produzida pela moderna sociedade capitalista que são conduzidos à mais completa dependência dessa divisão para a satisfação de suas carências. Mas, lembremos, trata-se da divisão do trabalho nos moldes do capitalismo, sob cujo domínio o trabalhador não é o proprietário dos meios de produção e nem daquilo que produz, mas sim um terceiro, o capitalista.

A propriedade privada moderna estabelece uma divisão do trabalho conservadora da acumulação, por um lado e, por outro, confirmadora da submissão do trabalhador às condições impostas pelo capital. "Por meio da divisão do trabalho, já está dada desde o princípio a divisão das condições de trabalho, das ferramentas e dos materiais, o que gera a fragmentação entre capital e trabalho, assim como as diferentes formas de propriedade" (Marx e Engels, 2007, p. 72, grifo dos autores).

Quanto mais se desenvolve a divisão do trabalho e a acumulação privada, mais se aprofunda a subsunção do trabalho ao pressuposto da fragmentação. Em se considerando que a produção da vida humana pelo trabalho engendra também a própria organização da produção, a produção capitalista gera a organização capitalista da vida. É com o surgimento da sociedade civil que o modo especificamente burguês de organização das relações sociais se universaliza.

Aqui se assenta um dos pilares para a compreensão da negatividade da política: Marx e Engels apresentam a sociedade civil como construção histórica, específica de uma época, desenvolvida somente com a ascensão da burguesia. A produção e o intercâmbio com base na propriedade privada burguesa criam um modo de organizar a vida em sociedade, um modo de os indivíduos viverem que constitui a base do Estado.

A sociedade civil abarca o conjunto do intercâmbio material dos indivíduos no interior de um estágio determinado das forças produtivas. Ela abarca o conjunto da vida comercial e industrial de um estágio e, nessa medida, ultrapassa o Estado e a nação, apesar de, por outro lado, ela ter de se afirmar ante o exterior como nacionalidade e se articular no interior como Estado. (Marx e Engels, 2007, p. 74).

Aqui se retoma uma importante reflexão que perpassa alguns textos marxianos, como, por exemplo, a Crítica da Filosofia do Direito de Hegel (1843): É o movimento da sociedade civil, da esfera da produção, que determina a atividade do Estado. O modo como essa sociedade civil se organiza, a forma como produz e reproduz a si mesma, é o

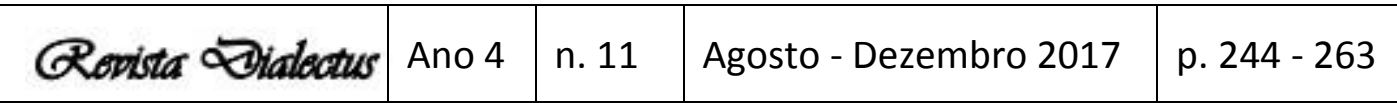


ponto de partida para a compreensão do Estado, que não é autônomo para encaminhar sua organização. Na concepção burguesa, ele é o gerenciador dos interesses particulares da classe que detém a propriedade dos meios de produção e só pode existir como expressão organizativa das relações de produção, demonstrando, à primeira vista e erroneamente, ser ele o detentor do poder determinante da sociedade.

Como instituição política subordinada, o Estado encaminha a justificação social e a imposição legal da forma privada de apropriação da produção social. O Estado só pode ser entendido a partir da sociedade civil e, na medida em que ela é regida pela expropriação, pela injustiça, pelos desequilíbrios sociais, pelo individualismo capitalista e pela propriedade privada dos meios de produção, então o Estado emerge como instância que expressa esse mesmo processo, justificadora de uma comunidade ilegítima e injusta (Chagas, 2014).

A sociedade civil contém todas as forças produtivas da sociedade; toda luta de classes; toda tensão entre produtores e proprietários de meios de produção. A base da sociedade civil é a produção, que não pode ser entendida, simplesmente, como um princípio econômico, posto que toda produção seja também uma forma de organizar a sociedade. O princípio regulador que mantém e salvaguarda o modelo de distribuição daquilo que é produzido é político. A produção, então, não é simplesmente uma esfera técnica da vida humana, mas um princípio político ao encaminhar determinada maneira de organizar as relações sociais. Na sociedade capitalista, a política democrático burguesa impõe a oficialização, justificação, legalização e institucionalização da dominação de classe.

Como o Estado é a forma na qual os indivíduos de uma classe dominante fazem valer seus interesses comuns e que sintetiza a sociedade civil inteira de uma época, segue-se que todas as instituições coletivas são mediadas pelo Estado, adquirem por meio dele uma forma política. (Marx e Engels, 2007, p. 76).

Então, como a política é transformada em aparato burocrático, em instrumento de negação do humano, em algo desvinculado de sua base real? Quando analisam o atraso da burguesia alemã em relação aos franceses e ingleses, a partir dos textos de Max Stirner, Marx e Engels abordam o liberalismo como sendo a própria política burguesa. Os jovens autores alemães apresentam, problematizam e criticam o

\begin{tabular}{|c|c|c|c|c|}
\hline Qevista Dialectus & Ano 4 & n. 11 & Agosto - Dezembro 2017 & p. $244-26$ \\
\hline
\end{tabular}


liberalismo político, dando uma importante contribuição para o entendimento da negatividade da política.

Embora com pretensões cosmopolitas, a burguesia alemã de meados do século XIX, época em que A Ideologia Alemã foi escrita, era ainda provinciana e dependente da velha nobreza, nunca se tornou revolucionária (Marx e Engels, 2007, p. 193). Enquanto o tear manual alcançava alguma importância na Alemanha, na Inglaterra ele era substituído por máquinas. Embora numerosa, a burguesia alemã era fragmentada e frágil, correspondendo a isso "a fragmentação da organização política, os pequenos principados e as cidades-reinos" (Marx e Engels, 2007, p. 194).

Quando o liberalismo francês, baseado em reais interesses de classe, chegou à Alemanha, foi recebido como expressão da vontade livre, sem que a burguesia alemã se desse conta de que, por trás dessa vontade, havia os interesses materiais dos franceses. A determinação do liberalismo como vontade humana é a materialização da vontade burguesa como injunção ideológica e conceitual. O liberalismo burguês se apresenta como vontade livre, mas esconde o fato de ser a imposição de um interesse particular de uma classe em particular.

Tais interesses apresentam-se nos Direitos do Homem, proclamados pela revolução como interesses universais. A universalização dos interesses franceses e o provincianismo e localismo dos alemães denunciam, para Marx e Engels (2007), o atraso da burguesia germânica. Enquanto o liberalismo avança com o ideário da revolução francesa, os pressupostos burgueses tornam-se universais. O liberalismo é a expressão ideológica e política da organização das forças produtivas mais desenvolvidas da Europa (Inglaterra e França), ou seja, dos interesses da burguesia, utilizados como instrumento político, por exemplo, dirigidos à expansão dos Direitos do Homem, uma vez que sua universalização é a efetivação da universalidade do indivíduo burguês (Marx e Engels, 2007, p. 194).

A expansão do ideário burguês tem como objetivo, primeiramente, a superação das relações feudais, que obstam o desenvolvimento capitalista. Em segundo lugar, a concretização das relações burguesas dão corpo ao cidadão moderno como padrão para o indivíduo da sociedade civil. O cidadão é aquele que materializa os direitos do homem, portanto, é o burguês concreto, livre negociador, despido dos andrajos medievais e pronto para incorporar-se à venalidade universal.

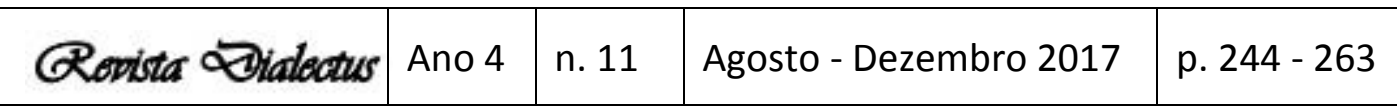


Quando o movimento de tornar todo indivíduo em cidadão está efetivado, a burguesia conclui também a emancipação política, cuja expressão ideológica é o liberalismo político. Aparentemente, a emancipação política encaminha a liberdade de tal modo que, independente da classe social, o cidadão pode vir a assumir o poder político, posto ser livre. Na errônea conclusão de Stirner (Cf. Marx e Engels, 2007, p. 197), seria possível, mesmo, que o Estado fosse dirigido por um monarca absoluto, ou seja, para a burguesia, não seria importante assumir o poder do Estado, uma vez que a emancipação esteja efetivada, bem como a forma do próprio Estado.

Mas Stirner desconsidera os interesses conflitantes no interior da própria burguesia e o confronto necessário entre os interesses burgueses e dos trabalhadores. Sobre os conflitos no interior da burguesia, a concorrência fomenta e encaminha a necessidade de medidas protecionistas, que só se fazem possíveis na medida em que extratos da burguesia assumam o poder político (Marx e Engels, 2007, p. 197). Isso significa que nem a burguesia é uma unidade e nem o Estado um campo de poder pacificado. Os burgueses conflitam-se entre si a fim de fazer uso do poder político e, com ele, legitimar interesses particulares como sendo universais.

Sobre os interesses conflitantes entre burgueses e trabalhadores, Marx e Engels (Cf. 2007, p. 198-9) descrevem a visão de Stirner de que o proletariado não tem interesses diferentes daqueles propagandeados e defendidos pela burguesia, ou seja, o liberalismo é também um modelo que interessa aos trabalhadores. Ademais, Stirner aponta que "[O] proletariado inteiro se compõe, portanto, de burgueses arruinados e proletários arruinados, de um conjunto de vadios [lumpem] que existiram em todas as épocas” (Marx e Engels, 2007, p. 199. Grifo dos autores).

Com esta visão, apresenta-se um entendimento do proletariado igual ao da burguesia e, em se considerando essa visão, parece mesmo que, para os burgueses, não haveria razões para se ocupar o poder político. Mas a realidade mostra um movimento muito diferente daquele que Stirner se esforça em demonstrar. Mostra que, a fim de tornar seus interesses particulares em universais, a burguesia não pode prescindir do poder político. O liberalismo só pode ser efetivado como interesse burguês através do exercício do poder político, do domínio do Estado e das instâncias burocráticas que encaminham o conjunto ideológico da burguesia como ideário a ser defendido, inclusive, pelos trabalhadores.

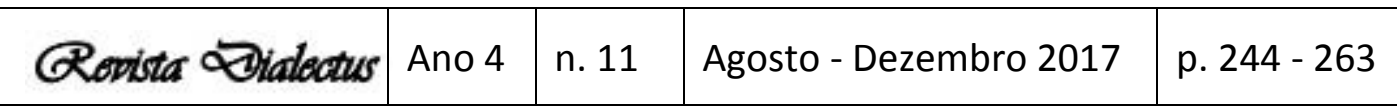


Ora, como o Estado é a instância reguladora da sociedade civil, estando ele jungido ao liberalismo político tornar-se-á instrumento de justificação, ratificação e perenização do modelo de apropriação privada dos produtos sociais. De certo modo, Stirner tem razão quando considera ser desnecessário à burguesia assumir o controle do Estado, mas não pelas razões harmoniosas que ele apresenta e imagina estarem presentes no desenvolvimento da "boa vontade" burguesa. O fato é que, se eventualmente alguma fração da classe burguesa não estiver no controle do Estado, o liberalismo político é a garantia de que o capital esteja sempre no poder.

Isso quer dizer que, em última instância, o dono dos meios de produção tem o poder de regular a vida daquele que vende sua força de trabalho. Essa regulação aparece, no liberalismo burguês, na forma política das leis, uma vez que o poder, o conhecimento e os instrumentos para redigi-las e fazê-las cumprir é da classe dominante. As leis não são, portanto, elaborações baseadas na vontade livre e tampouco nas boas intenções, mas sim submetidas aos interesses dominantes em uma sociedade. No caso da sociedade capitalista, os interesses de manutenção, aprofundamento e perenização dos interesses privados garantem, no plano político, a dominação concreta.

Essa dominação apresenta-se na produção de ideias. Quando se trata de uma realidade cujas bases assentam-se na desigualdade, é preciso produzir um conjunto de justificações, que devem ser internalizadas por aqueles a quem justamente essa realidade avilta e violenta. A ideologia, nesse sentido, assume uma função política: manipular as opiniões conforme os movimentos do modo de organização societária, construindo distorções sobre a base material da sociedade e garantindo o prolongamento dos interesses da classe dominante.

É por isso que a dominação de classe necessita investimento e dedicação na produção de ideias justificadoras, ela não pode se efetivar se não for profunda, extensa e constantemente repetida e reforçada. Essa dedicação se apresenta na formação, manutenção e notoriedade de produtores de ideias que sirvam bem aos interesses da classe dominante. Mészáros (2004) chama tais produtores de "intelectuais dominantes", por conta de sua privilegiada posição na ordem social estabelecida. Gramsci (1995) os identificou como "intelectuais orgânicos", cujas produções devem imiscuir-se na vida prática a fim de organizar e persuadir. Para Marx e Engels, o surgimento de produtores de ideias se dá na divisão do trabalho, que faz surgir, na classe dominante, "Os

\begin{tabular}{|c|c|c|c|c|}
\hline Qevista Dialectus & Ano 4 & n. 11 & Agosto - Dezembro 2017 & p. $244-26$ \\
\hline
\end{tabular}


pensadores dessa classe, como seus ideólogos ativos, criadores de conceitos, que fazem da atividade de formação de ilusão dessa classe sobre si mesma o seu meio principal de subsistência” (Marx e Engels, 2007, p. 48).

Como produtores intelectuais, são responsáveis pelo desenvolvimento de concepções ilusórias a respeito da sociedade, tornando as ideias de uma classe particular universalizadas. Nesse movimento, as ideias dominantes passam a ser defendidas até mesmo pela classe trabalhadora, mesmo que elas sejam a antítese de seus interesses históricos. A partir deste ponto, a produção de ideias e conceitos dominantes se converte em um princípio político.

O princípio político efetiva-se na institucionalização da concepção ilusória quando ela é transformada em lei e imprime legitimidade às ideias particulares. É assim que a ideologia, como produção de concepções ilusórias, transforma-se em regulação legislada para uma sociedade que se assenta e se organiza nos marcos do interesse particular de uma classe. É assim que a propriedade privada dos meios de produção, por exemplo, é defendida como essencial à natureza humana e transformada em lei pétrea, em fundamento estático da sociedade.

Essa fração de classe não pode ser amadora, mas constituir-se como corpo burocrático profissional cuja finalidade seja manter e conservar a organização social, gerenciando suas contradições, operando nos aspectos emergenciais e interferindo diretamente nas contingências que podem, de algum modo, pôr em xeque os interesses dominantes. De modo algum esse aparato burocrático profissional pode atacar a essência dos desequilíbrios sociais ocasionados pela apropriação desigual do excedente. “A política democrática e o Estado não têm fins próprios, não são autônomos, pois eles têm como meta salvaguardar os interesses particulares da sociedade civil, cujo alicerce fundamental é a propriedade privada" (Chagas, 2014, p. 78).

Outro ponto importante acerca do aparato burocrático profissional é o seu distanciamento em relação à sociedade civil. A constituição de uma fração de classe destinada à política torna o Estado um aparelho tão técnico e tão complexo que somente mediante a atuação exclusiva dos "políticos" é que se torna possível compreender seu papel como garantidor da ordem social existente. E, para assessorar os políticos, um exército de auxiliares profissionais compõe o conjunto do corpo burocrático do Estado.

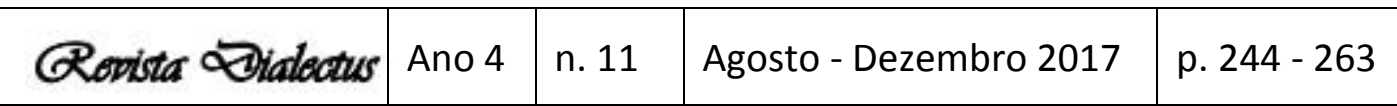


A negatividade da política na sociedade liberal burguesa torna-se evidente quando o indivíduo, o cidadão, integrante da ilusória comunidade em que se efetiva a sociedade civil vê-se completamente isolado da política, dos interesses do Estado. O isolamento do indivíduo em relação à sua comunidade é a realização do estranhamento do ser humano, da própria negação das possibilidades de desenvolvimento das potencialidades humanas através da organização política da sociedade. O Estado mais poderoso é aquele que naturaliza as relações sociais existentes como as únicas possíveis.

\section{Considerações Finais}

E por que o reforço constante das ideias que justificam o poder do capital é tão importante? Porque é através desse reforço que essas ideias são incorporadas como expressões de interesses universais, obstruindo, assim, o surgimento de ideias revolucionárias. As ideias de uma classe particular, quando apresentadas como as ideias necessárias à existência da sociedade inteira, instauram uma dominação que se configura ampla, profunda e aguda.

Não existe, para Marx e Engels (2007) uma comunidade humana sem política, posto que seja uma instância ineliminável da existência. Desde que produzam a própria vida, os indivíduos humanos criam também uma organização social correspondente a essa atividade. O ponto fundamental é que toda produção humana é social, criadora de relações auto-organizativas. A atividade produtiva é a própria práxis humana por ser criadora de ideias, de representações sobre o mundo. A práxis é inconcebível sem uma forma de organizar a sociedade, sem um princípio político que expresse as ideias em torno da organização da própria sociedade. É assim que se entende que as ideias não são autônomas, não fundam a realidade, mas a representam. Nenhuma ideia existe a priori, mas como expressão e reconstrução da realidade na consciência.

As ideias, portanto, são o modo pelo qual o indivíduo reconstrói o mundo sensível. Elas são sempre um a posteriori. Quando a ideia representa o mundo sensível de forma acrítica, ou seja, quando não busca sua essência, então uma reconstrução parcial e insuficiente se apresenta. É nesse sentido que se pode falar em ideias falsas, que podem, e efetivamente o são, ser criadas com a finalidade de falsear o mundo.

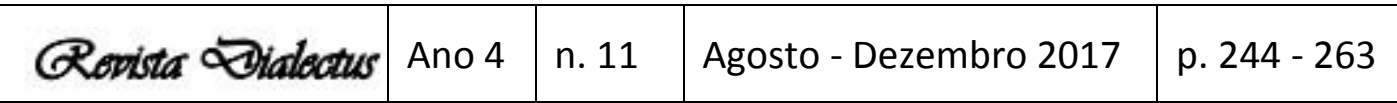


A política, então, é a concretização das ideias que encaminham a organização da sociedade, o modo como os indivíduos procedem, a regulação das relações entre os indivíduos e a forma pela qual a produção é distribuída. As ideias construídas a partir de uma determinada forma de organizar a produção encaminham a justificação e a representação dessa própria produção. A divisão do trabalho é uma forma de regulação política. No caso da sociedade capitalista, essa divisão, que não é necessariamente algo condenado por Marx e Engels, é submetida aos interesses e à determinação do capital.

A dominação de classe não se dá unicamente pelo domínio dos meios de produção, mas também pelas produções intelectuais como representações destinadas a falsear o mundo, naturalizando a exploração e a desigualdade. $\mathrm{O}$ instrumento para tal finalidade é a política liberal, responsável por imprimir à sociedade toda interesses particulares de uma classe. A dominação se dá no campo ideológico quando as ideias particulares tornam-se o fundamento político universalizado, produzindo uma concepção ilusória da própria sociedade.

Nesse sentido, o liberalismo político é a efetivação da desefetivação humana; é a negatividade da política em sua acepção mais crua; é a irracionalidade gestada e nutrida pela produção de ideias falseadas. A Ideologia Alemã apresenta elementos para a reflexão acerca do papel político da ideologia para o domínio de classe. A política, instância de afirmação do humano, nos marcos da sociedade capitalista e do liberalismo torna-se um instrumento destinado a enraizar um arranjo no qual o poder sobre a sociedade deve ser exercido através do consenso.

O poder sobre a sociedade só se efetiva a partir do domínio das instâncias formais do Estado. Para a burguesia é estrategicamente interessante exercer seu poderio político através do domínio do Estado. Entretanto, o consenso político possibilita ao capital permanecer no poder ainda que o Estado não esteja sob o domínio burguês. Aliás, independente da fração de classe que esteja na direção do Estado, quem está no poder é, invariavelmente, o capital (Cf. Mézáros, 2004, p. 144). É por isso que o poder do Estado não pode ser exercido contra ele mesmo.

É preciso superar a contradição entre a positividade e a negatividade da política a partir de um projeto de sociedade que supere, também, as formas da organização política até aqui engendradas, todas elas com base na propriedade privada. Em $A$ Ideologia Alemã, o comunismo é apresentado como superação da ideologia burguesa,

\begin{tabular}{|l|l|l|l|l} 
Gevista Dialectus & Ano 4 & n. 11 & Agosto - Dezembro 2017 & p. $244-263$ \\
\hline
\end{tabular}


mas somente quando os comunistas tiverem o "poder" para tanto (Cf. Marx e Engels, 2007, p. 214). Esse poder deve ser também construído. Em primeiro lugar, não é um poder natural, mas, histórico, demanda dos comunistas a apropriação de uma totalidade de instrumentos sociais. Superar a organização política burguesa e o poder do capital significa haver intelectuais produzindo ideias contrárias às ideias liberais burguesas. A transformação profunda da sociedade (emancipação humana) pressupõe pensamento e ação engajados. Braços, corações, mentes e a convicção de que um mundo justo pode ser construído exigem a produção de ideias contrárias ao liberalismo burguês e a luta pela superação do capitalismo formando um só bloco revolucionário. A superação da política liberal burguesa não pode ser efetivada a partir da própria política liberal burguesa, mas pela completa superação dela. As contradições presentes na concepção ilusória do mundo devem ser os objetos da reflexão e da ação revolucionária.

Em segundo lugar, a negação do consenso liberal e da conciliação de classe reformista deve encaminhar a mobilização dos trabalhadores. As contradições presentes na concepção ilusória devem ser o objeto da reflexão comunista. Mas a negação das concepções ilusórias precisa ser qualificada com a formação dos trabalhadores, com a organização de processos formativos que possibilitem aos trabalhadores apropriarem-se do método científico, municiando-os com as armas da crítica.

É claro para Marx e Engels (2007) que o comunismo é a alternativa para possibilitar aos indivíduos desenvolverem-se livremente, estabelecendo entre si relações verdadeiramente humanas. A construção dessa alternativa só se pode realizar com a revolução, com a emancipação humana. E a revolução é a expressão de uma necessidade histórica capaz de produzir indivíduos construtores de instituições sociais novas, superando a velha sociedade e a velha política burguesas, baseadas na propriedade privada e encaminhando um mundo novo, livre e efetivamente humano.

\section{REFERÊNCIAS:}

CHAGAS, Eduardo F. A Crítica à Política em Marx. Revista Dialectus. Fortaleza: ano $2 \quad \mathrm{n}^{\mathrm{o}}$ 5, Ago-Dez. 2014, p. 64-80. Disponível em http://www.revistadialectus.ufc.br/index.php/RevistaDialectus/article/view/186/117.

GRAMSCI. Antonio. Os Intelectuais e a Organização da Cultura. Rio de Janeiro: Civilização Brasileira, 1995.
Qonista Dialectus Ano 4
n. 11
Agosto - Dezembro 2017
p. $244-263$ 
HARVEY, David. 17 Contradições e o Fim do Capitalismo. São Paulo: Boitempo, 2016.

MARX, Karl e ENGELS, Friedrich. Ideologia Alemã. São Paulo: Boitempo, 2007.

MARX, Karl. Manuscritos Econômico-Filosóficos. São Paulo: Boitempo, 2009.

MATA, Vilson Aparecido da. Negatividade e Positividade da Política em Marx: A partir das Glosas Críticas Marginais. Revista Dialectus. Fortaleza: ano $2 \mathrm{n}^{\circ} 5$, AgoDez. 2014, p. 80-96. Disponível em

http://www.revistadialectus.ufc.br/index.php/RevistaDialectus/article/view/176/118

MÉSZÁROS, István. O Poder da Ideologia. São Paulo: Boitempo, 2004. 